\title{
IDENTIFIKASI MARKA GEN KETAHANAN HAWAR DAUN BAKTERI PADA GALUR PADI INTRODUKSI DAN GALUR DIHAPLOID
}

\author{
Ovi Prasetya Winandari ${ }^{1}$, Aris Tjahjoleksono ${ }^{2}, \&$ Dwinita Wikan Utami $^{3}$ \\ 'Program Studi Biologi Tumbuhan, Departemen Biologi, Institut Pertanian Bogor \\ ${ }^{2}$ Departemen Biologi, Institut Pertanian Bogor, Dramaga Bogor 16680, Indonesia \\ ${ }^{3}$ Balai Besar Penelitian dan Pengembangan Bioteknologi dan Sumberdaya Genetik Pertanian \\ (BB-BIOGEN), Bogor 16111, Indonesia \\ E-mail: dnitawu@ windowslive.com/081388019811
}

\begin{abstract}
Identification marker of bacterial leaf blight (BLB) gene resistance on introducted and dihaploid rice germplasm. Bacterial leaf blight (BLB), caused by bacterial pathogen Xanthomonas oryzae pv. oryzae (Xoo), is one of the most devastating diseases in rice. The use of BLB-resistant rice varieties is one of the most efficient ways to protect rice from this disease. BLBresistant varieties can be produced through the breeding program by using the diverse rice germplasm. The objective of this research was to identify BLB resistance gene on 37 introducted and dihaploid rice lines derived from wide genetic background double crossing from local rice : IR54/Parekaligolara and Bio110/Markuti, by using the molekular markers. As control plant used 23 differential varieties (monogenic lines/IRBB) and TN1 (susceptible). All plants tested were inoculated by 3 selected dominant BLB races (Race III, IV dan VIII). The selected of 19 polymorphism molecular markers used to identify the BLB resistance genes on rice lines tested. The result of this research showed that 4 rice lines were resistance to all BLB races tested. Three molecular markers were specific associated with resistant gene to Race III (Xa7-STS40, Xa1-STS14 and Xa4STS50); Race IV (Xa1-STS5, Xa4-STS50 and Xa26-STS1), and Race VIII (Xa21-STS6, Xa7-RM20590 and Xa7-STS40). These markers could be utilized for the selection process the developmen of BLB resistance rice lines breeding program.
\end{abstract}

Key words: double crossing, markers associated, molekular markers

\begin{abstract}
ABSTRAK
Identifikasi marka gen ketahanan hawar daun bakteri pada galur padi introduksi dan galur dihaploid. Hawar Daun Bakteri (HDB), merupakan salah satu penyakit utama pada padi yang disebabkan oleh bakteri patogen Xanthomonas oryzae pv. oryzae (Xoo). Penggunaan varietas tahan HDB dipandang sebagai cara efisien untuk melindungi tanaman padi dari penyakit HDB. Perakitan varietas padi tahan HDB dapat dilakukan dengan persilangan beberapa sumber plasma nutfah padi. Penelitian ini bertujuan untuk mengidentifikasi gen tahan penyakit HDB pada 37 galur padi introduksi dan galur dihaploid yang diperoleh dari hasil persilangan ganda beberapa aksesi plasma nutfah padi lokal, IR54/Parekaligolara dan Bio110/ Markuti, menggunakan marka molekuler. Sebagai tanaman kontrol digunakan 22 varietas diferensial (monogenic lines/ IRBB) dan TN1, sebagai tanaman kontrol peka. Tanaman-tanaman uji di inokulasi dengan 3 Ras HDB dominan (Ras III, IV dan VIII). Berdasarkan survei polimorfisme antara tanaman tahan dan peka, terdapat 19 marka polimorfis yang selanjutnya digunakan untuk menyeleksi galur-galur uji. Hasil penelitian menunjukkan bahwa dari 37 galur yang diuji terdapat 4 galur bersifat tahan terhadap ketiga ras uji. Galur-galur ini sebagai calon galur harapan setelah diuji potensi daya hasilnya. Tiga marka terdeteksi spesifik menandai sifat ketahanan terhadap: Ras III (Xa7-STS40, Xa1-STS14 dan Xa4-STS50), Ras IV (Xa1-STS5, Xa4-STS50, Xa26-STS1) dan Ras VIII (Xa21-STS6, Xa7-RM20590 dan Xa7-STS40). Marka-marka ini dapat digunakan untuk membantu proses seleksi dalam program pembentukan galur tahan HDB.
\end{abstract}

Kata kunci: asosiasi marka, marka molekuler, persilangan ganda

\section{PENDAHULUAN}

Padi (Oryza sativa L.) merupakan salah satu tanaman pangan utama di dunia (Mudingotto et al., 2010). Di Indonesia, padi merupakan bahan makanan pokok sehingga kebutuhan padi semakin meningkat setiap tahunnya (Siregar, 2007) seiring dengan peningkatan jumlah penduduk. Peningkatan kebutuhan terhadap padi tidak berbanding lurus dengan peningkatan produksi padi. Berdasarkan data dari BPS (2011), produktivitas padi mengalami penurunan sebanyak 1,08 juta ton $(1,63 \%)$ per tahun sedangkan laju pertumbuhan 
penduduk meningkat $1,49 \%$ per tahun. Oleh karena itu, sejalan dengan peningkatan jumlah penduduk, maka peningkatan produksi padi harus senantiasa diupayakan. Upaya peningkatan produksi padi tidak terlepas dari kendala-kendala cekaman biotik dan abiotik. Cekaman biotik antara lain serangan hama seperti wereng coklat, penggerek batang dan ganjur, serta penyakit seperti Hawar Daun Bakteri (HDB) dan Blas. Cekaman abiotik meliputi kekeringan, keracunan besi $(\mathrm{Fe})$ dan $\mathrm{Al}$ (aluminium) (Abdullah et al., 2001).

Penyakit hawar daun bakteri menyebabkan penurunan produksi padi yang cukup tinggi. Di Indonesia, HDB menyebabkan penurunan hasil panen yang signifikan dan dalam keadaan tertentu dapat menurunkan produksi sampai $60 \%$ (Triny et al., 2011). Penyakit HDB merupakan penyakit yang disebabkan oleh bakteri patogen Xanthomonas oryzae pv. oryzae (Xoo) (Wahyudi et al., 2011).

Indonesia dikenal memiliki keanekaragaman spesies padi yang tinggi dan memiliki sekitar 17.000 aksesi plasma nutfah (Fitriyanti, 2008). Keragaman genetik plasma nutfah padi merupakan pondasi program pemuliaan tanaman padi. Di antara koleksi plasma nutfah padi yang memiliki keragaman genetik yang luas adalah aksesi padi lokal (landraces) dan aksesi galur-galur introduksi dari luar negeri (Utami et al., 2011).

Ketersediaan aksesi plasma nutfah yang beragam telah dimanfaatkan oleh Balai Besar Penelitian dan Pengembangan Bioteknologi dan Sumberdaya Genetik (BB-Biogen) sebagai sumber genetik untuk melakukan pembentukan galur-galur padi baru yang diantaranya ditargetkan sebagai galur padi tahan penyakit HDB. Galur-galur padi yang digunakan pada penelitian ini meliputi varietas diferensial dan galur-galur yang diantaranya merupakan galur hasil persilangan ganda antara padi Parekaligolara/IR54 dengan padi BIO 110/ Markuti. Padi Parekaligolara memiliki gen ketahanan terhadap patogen HDB, IR54 memiliki gen ketahanan terhadap patogen Blas dan gen toleran terhadap kahat P, BIO 110 memiliki gen ketahanan HDB dan Blas, dan Markuti memiliki gen toleran terhadap keracunan $\mathrm{Fe}$ (Utami et al., 2009). Di samping itu juga telah diintroduksi galur-galur yang berasal dari IRRI yang berpotensi memiliki sifat-sifat unggul yang tahan penyakit HDB. Berdasarkan ketersediaan galur-galur padi di atas, maka perlu dilakukan identifikasi adanya gen ketahanan terhadap penyakit HDB baik secara fenotipe dengan inokulasi buatan maupun secara genotipe dengan menggunakan marka molekuler. Tujuan dari penelitian ini adalah mengidentifikasi gen ketahanan penyakit Hawar Daun Bakteri pada galur-galur padi introduksi dan galur-galur dihaploid baik secara fenotipe ataupun genotipe.

\section{METODE PENELITIAN}

Tempat dan Waktu. Penelitian ini dilaksanakan pada bulan Januari sampai Desember 2013 di Laboratorium Biologi Molekuler, Balai Besar Bioteknonogi dan Sumber Daya Genetik Pertanian (BB-Biogen), Bogor.

Bahan Penelitian. Populasi tanaman yang diuji berjumlah 37 galur yang terdiri atas galur-galur introduksi dan galur-galur dihaploid dari hasil persilangan beberapa padi terpilih, yaitu IR54/Parekaligolara//Bio110/Markuti. Sebanyak 22 varietas padi diferensial yang telah diketahui memiliki gen ketahanan HDB juga digunakan sebagai pembanding sifat ketahanan padi yang diuji. Varietas IRBB7 digunakan sebagai kontrol tahan dan TN1 sebagai kontrol peka. Evaluasi fenotipe, setiap tanaman diuji ketahanannya terhadap Ras III, IV dan VIII. Evaluasi genotipe, DNA diekstrak dari daun masing-masing galur untuk mengamplifikasi gen ketahanan HDB. Sebanyak 208 primer yang digunakan terdiri atas primer untuk marka Simple Sequence Repeat (SSR) gen $\mathrm{Xa} 7$ dan primer untuk marka Sequence Taq Site (STS) genXa1, Xa4, Xa7, Xa13, $X a 21, X a 22$, dan Xa26. Uji polimorfisme dilakukan terhadap varietas IRBB7 dan TN1. Kemudian marka yang bersifat polimorfisme digunakan dalam uji genotipe sifat ketahanan galur-galur uji dan galur diferensial terhadap penyakit HDB.

Penyiapan Inokulum Bakteri. Inokulum bakteri Xanthomonas oryzae disiapkan dengan cara meremajakan isolat yang telah tersedia yaitu Ras III, IV dan VIII pada cawan Petri dengan media agar (20 g sukrose, $5 \mathrm{~g}$ peptone, $0,5 \mathrm{~g} \mathrm{Ca}\left(\mathrm{NO}_{3}\right)_{2} \cdot 4 \mathrm{H}_{2} \mathrm{O}, 1,8 \mathrm{~g}$ $\mathrm{Na}_{2} \cdot 4 \mathrm{PO}_{4} \cdot 7 \mathrm{H}_{2} \mathrm{O}, 0.05 \mathrm{~g} \mathrm{FeSO}_{4} \cdot 7 \mathrm{H}_{2} \mathrm{O}, 18 \mathrm{~g}$ Bacto Agar dalam 1 liter $\mathrm{dH}_{2} \mathrm{O}$ ). Bakteri diinkubasikan di dalam inkubator bersuhu $37^{\circ} \mathrm{C}$ selama 3 hari.

Penyiapan Tanaman. Benih padi varietas diferensial maupun galur uji dikecambahkan dengan cara direndam air dalam cawan Petri selama 1 minggu sebelum penanaman. Selanjutnya, kecambah ditanam dalam pot plastik $(40 \times 30 \times 12 \mathrm{~cm})$ yang telah diisi dengan media tanah. Enam benih per galur ditanam dalam setiap baris.

Inokulasi Bakteri. Bakteri yang telah tumbuh pada cawan Petri kemudian diresuspensikan dengan $\mathrm{ddH}_{2} \mathrm{O}$ sebanyak $25 \mathrm{ml}$ menggunakan spatula. Selanjutnya 
suspensi bakteri dipindahkan ke dalam labu Erlemeyer $50 \mathrm{ml}$ dan digunakan sebagai inokulum. Inokulasi pada tanaman dilakukan dengan cara memotong ujung daun ke-3 dan ke-4 dari setiap tanaman menggunakan gunting yang sebelumnya dicelupkan ke dalam suspensi bakteri. Inokulasi dilakukan ketika tanaman berumur 1 bulan.

\section{Pengamatan Fenotipe dan Evaluasi Ketahanan.} Pengamatan terhadap penyakit HDB dilakukan pada hari ke-14 setelah proses inokulasi. Intensitas serangan bakteri dihitung dengan membagi panjang serangan dengan panjang daun yang diinokulasi. Hasil pengamatan terhadap tingkat keparahan serangan Xoo, diklasifikasikan berdasarkan kriteria ketahanan menurut Standard Evaluation System (IRRI, 1996).

Isolasi DNA. Isolasi DNA dilakukan berdasarkan metode Doyle \& Doyle (1990). Daun tanaman direndam di dalam nitrogen cair kemudian dimasukkan ke dalam mesin TissuelyserII Qiagen untuk proses perusakan dinding sel. Sampel ditambah dengan $750 \mu$ larutan penyangga cetyltrimethyl ammonium bromide (CTAB) dan diinkubasi pada suhu $60^{\circ} \mathrm{C}$ selama 30 menit. Sampel ditambah dengan $750 \mu$ l kloroform:isoamil-alkohol (24:1) dan disentrifugasi dengan Legend Micro $17 R$ centrifuge selama 5 menit pada suhu $4^{\circ} \mathrm{C}$ dengan kecepatan $12.000 \mathrm{rpm}$. Supernatan diambil sebanyak $500 \mu \mathrm{L}$ dan dipindahkan ke dalam tabung baru, kemudian ditambah $100 \mu \mathrm{l}$ natrium asetat $3 \mathrm{M} \mathrm{pH}$ 5,2 dan $1000 \mu \mathrm{l}$ etanol absolut. Sampel didiamkan di dalam lemari es selama 60 menit. Selanjutnya dilakukan sentrifugasi kembali pada $12.000 \mathrm{rpm}$ dengan suhu $4^{\circ} \mathrm{C}$ selama 10 menit. Selanjutnya supernatan dibuang kemudian endapan ditambah dengan $200 \mu \mathrm{l}$ etanol $70 \%$ untuk membilas. Endapan tersebut kemudian dikeringkan dan dilarutkan dalam $100 \mu \mathrm{L} \mathrm{TE}$ (Tris-HCl $40 \mathrm{mM} \mathrm{pH} \mathrm{8,3,}$ EDTA $1 \mathrm{mM}$ ) sebagai larutan stok DNA dan ditambahkan RNAse (SIGMA) $100 \mu \mathrm{g} / \mu \mathrm{l}$ sebanyak 1,5 $\mu \mathrm{l}$ agar diperoleh DNA yang tidak terkontaminasi oleh RNA.

Amplifikasi DNA. PCR dilakukan dalam dua tahap, tahap pertama adalah PCR untuk uji survei polimorfisme, dimana marka yang menghasilkan pita polimorfisme digunakan untuk tahap PCR yang kedua yaitu PCR untuk uji genotipe semua galur padi. Dari 208 primer yang digunakan, ada 19 primer yang menunjukkan pita polimorfisme (Tabel 1). Reaksi PCR dilakukan dengan menggunakan volume $10 \mu \mathrm{L}$ terdiri atas $4,5 \mu 1$ master mix PCR KAPA®BIOSYSTEMS US (larutan penyangga, dNTP, enzim Taq polymerase), 1,5 $\mu$ l primer $10 \mu \mathrm{M}$ (forward dan reverse), dan $4 \mu \mathrm{l}$ DNA $10 \mathrm{ng} / \mu \mathrm{l}$. Tahap-tahap PCR untuk marka STS meliputi proses denaturasi awal 4 menit pada suhu $95^{\circ} \mathrm{C}$, dilanjutkan denaturasi selama 45 detik pada suhu $95^{\circ} \mathrm{C}$, annealing selama 45 detik pada suhu $55^{\circ} \mathrm{C}$, ekstensi primer selama 30 detik pada suhu $72^{\circ} \mathrm{C}$. Tahap denaturasi, annealing dan ekstensi primer diulang sebanyak 27 kali, dengan program penurunan suhu annealing secara teratur dengan perbedaan sebanyak $0,5^{\circ} \mathrm{C}$ setiap siklusnya agar

Tabel 1. Primer hasil survei polimorfisme

\begin{tabular}{lcll}
\hline Nama primer & Jenis Marka & Sekuen primer forward $\left(5^{\prime} \rightarrow 3^{\prime}\right)$ & Sekuen primer reverse $\left(5^{\prime} \rightarrow 3^{\prime}\right)$ \\
\hline Xa1-STS5 & STS & TTTCTGGCGCTTTTCTTGT & CGACCAACAGCATGTACCAC \\
Xa1-STS7 & STS & TCATTCAATCAAATCTCAACTGAAG & CATGTTTTGGACGCTTCCTC \\
Xa1-STS13 & STS & ACGGCCCTACTGATCAATGC & TCGAGTTATGATGCGGATACAC \\
Xa1-STS14 & STS & CTAGCTTTTGAGGCGGTGAC & GGATGCACGAATACACTGCT \\
Xa1-STS15 & STS & CATGGAATCTTGCCCTAGA & CGCTATCGACCTGAGGAGAC \\
Xa1-STS31 & STS & CCTCTCTTGCTTCCTTGTGG & GCTCAAGCACTCACCAAACA \\
Xa4-STS28 & STS & TTTCTTCATGCTGGTGCTG & CAAGTCTTTTCCGCTTTTC \\
Xa4-STS44 & STS & GGGGCTCTAGGTTTTCCATC & GTAGGGAACCATGGATGTGG \\
Xa4-STS50 & STS & TTCGGGTATGCCTTGTTTC & GGCCGAATTACGTGTGAAGT \\
Xa7-STS40 & STS & CTACACACGCGAGGAAGACA & ATGGCAGTAGCGTAGCGAGT \\
Xa7-STS51 & STS & GAATTGGCCCAACTTTGAGA & TGGGATTTGGGATTTGGATA \\
Xa7-STS54 & STS & GGCAAGTGTTCGACCGTTAT & AGGCCTAAGAAAGGCGAAAG \\
Xa13-STS51 & STS & ACGTGTCCAATCAAAGCACA & GTCAAACGTTGCAAGCAAAA \\
Xa21-STS6 & STS & AGCTAGCTGCTCGCAATCTC & CTAGCCTCGCCTTCTACGAC \\
Xa21-STS27 & STS & ATGAATCCCTGCCCGTCGTA & GATTCAGTACCTGACGAG \\
Xa22-STS17 & STS & TGCACACTTGGTTTCAGCTC & TCTCCTTTGCTACGGCAGAT \\
Xa26-STS1 & STS & TGACCTCACTGCACTTCTGG & TGGAGAGGTCCTATGGTG \\
Xa26-STS2 & STS & GTAAAGCGTCACGGAAGAGC & TTCTTCAACGTCACAACAACATC \\
Xa7-RM20590 & SSR & TTCGATGAGCACCTTTCCTTGTCC & GCCTCGCCGATTCACTTATGC \\
\hline
\end{tabular}


diperoleh suhu optimum untuk penempelan primer, kemudian diikuti dengan proses ekstensi primer akhir selama 5 menit pada suhu $72^{\circ} \mathrm{C}$. Tahap terakhir adalah inkubasi pada suhu $10^{\circ} \mathrm{C}$ selama 30 menit (Utami et al., 2011). Sedangkan proses PCR untuk marka SSR meliputi proses denaturasi awal 3 menit pada suhu $95^{\circ} \mathrm{C}$, dilanjutkan denaturasi selama 1 menit pada suhu $94^{\circ} \mathrm{C}$, annealing selama 1 menit pada suhu $50^{\circ} \mathrm{C}$, ekstensi primer selama 2 menit pada suhu $72^{\circ} \mathrm{C}$. Tahap denaturasi, annealing dan ekstensi primer diulang sebanyak 35 kali, kemudian diikuti dengan proses ekstensi primer akhir selama 5 menit pada suhu $72^{\circ} \mathrm{C}$. Tahap terakhir adalah inkubasi pada suhu $10^{\circ} \mathrm{C}$ selama 30 menit (Utami et al., 2009).

Produk PCR dipisahkan pada elektroforesis gel agarosa 2\% dalam Tris-acetic acid-EDTA (TAE) 1x pada tegangan $100 \mathrm{~V}$ selama 30 menit, kemudian divisualisasi dengan sinar UV setelah direndam dalam etidium bromida $(2 \mu \mathrm{g} / \mu \mathrm{l})$.
Analisis Data. Hasil uji genotipe diasosiasikan dengan hasil uji fenotipe. Analisis dilakukan menggunakan program Tassel 3.0 GLM (Bradbury et al., 2007). Marka yang berasosiasi dengan respon fenotipe $\left(P \_\right.$value kurang dari 0,05$)$ menunjukkan bahwa marka tersebut berasosiasi dengan respon ketahanan tanaman terhadap Ras penyakit HDB yang diinokulasikan.

\section{HASIL DAN PEMBAHASAN}

\section{Uji Fenotipe terhadap Respon Ketahanan Varietas} Diferensial (IRBB). Hasil uji fenotipe varietas diferensial menunjukkan adanya respon yang berbeda terhadap Ras III, Ras IV dan Ras VIII (Tabel 2). Di antara varietas-varietas diferensial yang memiliki satu gen ketahanan (monogenik), respon paling tahan ditunjukkan oleh varietas padi IRBB7 yang mengandung gen ketahanan $X a 7$, dimana varietas IRBB7 ini mampu bertahan terhadap serangan patogen Ras III, Ras IV dan ras VIII. Selanjutnya diikuti oleh varietas diferensial

Tabel 2. Respon ketahanan padi varietas diferensial terhadap HDB

\begin{tabular}{|c|c|c|c|c|c|c|c|}
\hline \multirow{3}{*}{$\begin{array}{l}\text { Varietas } \\
\text { /Galur }\end{array}$} & \multirow{3}{*}{ Gen } & \multicolumn{6}{|c|}{ Respon Ketahanan terhadap HDB } \\
\hline & & \multicolumn{2}{|c|}{ Ras-III } & \multicolumn{2}{|c|}{ Ras-IV } & \multicolumn{2}{|c|}{ Ras-VIII } \\
\hline & & IS $(\%)$ & Respon & IS $(\%)$ & Respon & IS $(\%)$ & Respon \\
\hline IRBB1 & Xal & 10,20 & $\mathrm{~T}$ & 36,00 & AT & 51,53 & $\mathrm{P}$ \\
\hline IRBB2 & $X a 2$ & 10,10 & $\mathrm{~T}$ & 37,08 & AT & 50,43 & $\mathrm{P}$ \\
\hline IRBB3 & $X a 3$ & 9,70 & $\mathrm{~T}$ & 49,75 & $\mathrm{P}$ & 56,35 & $\mathrm{P}$ \\
\hline IRBB4 & Xa4 & 9,70 & $\mathrm{~T}$ & 47,90 & $\mathrm{P}$ & 49,33 & $\mathrm{P}$ \\
\hline IRBB5 & Xa5 & 7,60 & $\mathrm{~T}$ & 12,08 & $\mathrm{~T}$ & 23,57 & AT \\
\hline IRBB7 & $X a 7$ & 0,00 & $\mathrm{~T}$ & 0,00 & $\mathrm{~T}$ & 0,00 & $\mathrm{~T}$ \\
\hline IRBB8 & $X a 8$ & 11,10 & $\mathrm{~T}$ & 46,83 & $\mathrm{P}$ & 32,05 & AT \\
\hline IRBB10 & Xalo & 11,20 & $\mathrm{~T}$ & 53,00 & $\mathrm{P}$ & 46,67 & $\mathrm{P}$ \\
\hline IRBB11 & Xall & 10,80 & $\mathrm{~T}$ & 52,38 & $\mathrm{P}$ & 50,22 & $\mathrm{P}$ \\
\hline IRBB13 & Xa13 & 9,00 & $\mathrm{~T}$ & 44,32 & $\mathrm{P}$ & 46,22 & $\mathrm{P}$ \\
\hline IRBB14 & $\mathrm{Xal} 4$ & 12,20 & $\mathrm{~T}$ & 53,25 & $\mathrm{P}$ & 43,22 & $\mathrm{P}$ \\
\hline IRBB21 & $X a 21$ & 5,60 & $\mathrm{~T}$ & 21,28 & AT & 15,88 & $\mathrm{~T}$ \\
\hline IRBB50 & $X a 4+X a 5$ & 5,40 & $\mathrm{~T}$ & 5,05 & $\mathrm{~T}$ & 11,82 & $\mathrm{~T}$ \\
\hline IRBB51 & $X a 4+X a 13$ & 10,10 & $\mathrm{~T}$ & 46,08 & $\mathrm{P}$ & 46,22 & $\mathrm{P}$ \\
\hline IRBB52 & $X a 4+X a 21$ & 4,20 & $\mathrm{~T}$ & 12,92 & $\mathrm{~T}$ & 9,45 & $\mathrm{~T}$ \\
\hline IRBB53 & $X a 5+X a 13$ & 3,40 & $\mathrm{~T}$ & 4,70 & $\mathrm{~T}$ & 6,25 & $\mathrm{~T}$ \\
\hline IRBB54 & $X a 5+X a 21$ & 3,80 & $\mathrm{~T}$ & 5,47 & $\mathrm{~T}$ & 5,62 & $\mathrm{~T}$ \\
\hline IRBB56 & $X a 4+X a 5+X a 13$ & 5,80 & $\mathrm{~T}$ & 5,63 & $\mathrm{~T}$ & 11,37 & $\mathrm{~T}$ \\
\hline IRBB57 & $X a 4+X a 5+X a 21$ & 10,00 & $\mathrm{~T}$ & 40,00 & AT & 30,35 & AT \\
\hline IRBB58 & $X a 4+X a 13+X a 21$ & 8,10 & $\mathrm{~T}$ & 8,82 & $\mathrm{~T}$ & 17,50 & $\mathrm{~T}$ \\
\hline IRBB64 & $X a 4+X a 5+X a 7+X a 21$ & 1,10 & $\mathrm{~T}$ & 0,22 & $\mathrm{~T}$ & 3,03 & $\mathrm{~T}$ \\
\hline IRBB66 & $X a 4+X a 5+X a 7+X a 13+X a 21$ & 1,20 & $\mathrm{~T}$ & 1,48 & $\mathrm{~T}$ & 3,22 & $\mathrm{~T}$ \\
\hline TN1 & & 43,70 & $\mathrm{P}$ & 79,93 & $\mathrm{P}$ & 63,65 & $\mathrm{P}$ \\
\hline
\end{tabular}

IS: Intensitas Serangan, T: Tahan, AT: Agak Tahan, P: Peka. 
Tabel 3. Respon ketahanan padi galur uji terhadap HDB

\begin{tabular}{|c|c|c|c|c|c|c|}
\hline \multirow{3}{*}{ Galur/Varietas } & \multicolumn{6}{|c|}{ Respon ketahanan terhadap HDB } \\
\hline & \multicolumn{2}{|c|}{ Ras III } & \multicolumn{2}{|c|}{ Ras IV } & \multicolumn{2}{|c|}{ Ras VIII } \\
\hline & IS $(\%)$ & Respon & IS $(\%)$ & Respon & IS (\%) & Respon \\
\hline IR 83821-95-3-2-3 & 50,26 & $\bar{P}$ & 61,32 & $\bar{P}$ & 65,52 & $\bar{P}$ \\
\hline IR 83860-503-1-1-2 & 37,88 & $\mathrm{AT}$ & 58,96 & $\mathrm{P}$ & 66,60 & $\mathrm{P}$ \\
\hline IR 83860-513-3-3-2 & 73,69 & $\mathrm{P}$ & 43,36 & $\mathrm{P}$ & 58,33 & $\mathrm{P}$ \\
\hline IR 84047-24-3-3-3 & 11,09 & $\mathrm{~T}$ & 20,68 & AT & 16,71 & $\mathrm{~T}$ \\
\hline IR 84941-12-1-2 & 39,79 & $\mathrm{AT}$ & 59,41 & $\mathrm{P}$ & 52,82 & $\mathrm{P}$ \\
\hline IR 83650-59-2-5-2-2 & 8,47 & $\mathrm{~T}$ & 3,21 & $\mathrm{~T}$ & 20,21 & AT \\
\hline IR 3822-5 12-3-2-2 & 8,47 & $\mathrm{~T}$ & 2,95 & $\mathrm{~T}$ & 15,08 & $\mathrm{~T}$ \\
\hline IR $83689-14-1-2-1-3$ & 25,97 & AT & 17,93 & $\mathrm{~T}$ & 42,49 & $\mathrm{P}$ \\
\hline IR 84744-94-3-3-2 & 83,71 & $\mathrm{P}$ & 22,80 & AT & 58,75 & $\mathrm{P}$ \\
\hline IR 84790-73-2-2-2 & 41,84 & $\mathrm{P}$ & 20,67 & AT & 62,39 & $\mathrm{P}$ \\
\hline IR 85627-46-1-2-3 & 45,77 & $\mathrm{P}$ & 23,20 & AT & 52,06 & $\mathrm{P}$ \\
\hline IR 82571-581-1-2-3 & 8,70 & $\mathrm{~T}$ & 10,04 & $\mathrm{~T}$ & 11,80 & $\mathrm{~T}$ \\
\hline IR 82571-602-3-2-2 & 8,89 & $\mathrm{~T}$ & 7,20 & $\mathrm{~T}$ & 13,94 & $\mathrm{~T}$ \\
\hline IR 82480-104-2-2-3-2 & 66,13 & $\mathrm{P}$ & 44,33 & $\mathrm{P}$ & 50,43 & $\mathrm{P}$ \\
\hline IR 10L 369 & 40,54 & $\mathrm{P}$ & 21,08 & AT & 52,45 & $\mathrm{P}$ \\
\hline IR 10L 440 & 54,38 & $\mathrm{P}$ & 71,87 & $\mathrm{P}$ & 64,49 & $\mathrm{P}$ \\
\hline IR 74371-70-1-1 & 51,15 & $\mathrm{P}$ & 64,32 & $\mathrm{P}$ & 71,09 & $\mathrm{P}$ \\
\hline IR 74371-54-1-1 & 52,98 & $\mathrm{P}$ & 73,25 & $\mathrm{P}$ & 75,99 & $\mathrm{P}$ \\
\hline IR 80311-10-B-B-2-B & 79,36 & $\mathrm{P}$ & 65,21 & $\mathrm{P}$ & 53,92 & $\mathrm{P}$ \\
\hline IR 77408-40-3-2-1-B & 49,88 & $\mathrm{P}$ & 36,00 & $\mathrm{AT}$ & 59,77 & $\mathrm{P}$ \\
\hline IR54741-1-244-15-2-3-B & 31,13 & $\mathrm{AT}$ & 7,60 & $\mathrm{~T}$ & 51,05 & $\mathrm{P}$ \\
\hline BERAS MERAHD1 & 5,56 & $\mathrm{~T}$ & 6,04 & $\mathrm{~T}$ & 12,26 & $\mathrm{~T}$ \\
\hline BM1P-46-4-1 & 23,50 & AT & 7,65 & $\mathrm{~T}$ & 29,92 & AT \\
\hline IPBM-32-1-3-3 & 27,31 & $\mathrm{AT}$ & 7,37 & $\mathrm{~T}$ & 32,11 & $\mathrm{AT}$ \\
\hline BMIP-18-4-4-1 & 30,58 & AT & 7,74 & $\mathrm{~T}$ & 37,39 & AT \\
\hline BMIP-18-4-4-2 & 40,00 & $\mathrm{AT}$ & 38,90 & AT & 45,90 & $\mathrm{P}$ \\
\hline BMIP-24-4-3-1 & 33,96 & AT & 38,34 & AT & 45,22 & $\mathrm{P}$ \\
\hline BMIP-204-3-2 & 30,79 & $\mathrm{AT}$ & 30,82 & AT & 43,18 & $\mathrm{P}$ \\
\hline BMIP-24-1-2-1 & 30,20 & $\mathrm{AT}$ & 31,21 & AT & 35,67 & $\mathrm{AT}$ \\
\hline BMIP-44-4-3-1 & 25,65 & AT & 22,87 & AT & 28,68 & AT \\
\hline BMIP-44-4-3-2 & 24,02 & $\mathrm{AT}$ & 21,63 & $\mathrm{AT}$ & 32,05 & $\mathrm{AT}$ \\
\hline BMIP-20-2-1-1 & 26,99 & $\mathrm{AT}$ & 27,96 & $\mathrm{AT}$ & 37,36 & $\mathrm{AT}$ \\
\hline IRHS -12-4-1 & 47,38 & $\mathrm{P}$ & 56,86 & $\mathrm{P}$ & 67,79 & $\mathrm{P}$ \\
\hline Ciherang & 25,71 & $\mathrm{AT}$ & 13,78 & $\mathrm{~T}$ & 54,00 & $\mathrm{P}$ \\
\hline Inpari 13 & 21,53 & $\mathrm{AT}$ & 6,03 & $\mathrm{~T}$ & 36,61 & AT \\
\hline Code & 15,89 & $\mathrm{~T}$ & 1,71 & $\mathrm{~T}$ & 28,53 & $\mathrm{AT}$ \\
\hline IR64 & 63,79 & $\mathrm{P}$ & 64,92 & $\mathrm{P}$ & 54,10 & $\mathrm{P}$ \\
\hline IRBB7 & 14,46 & $\mathrm{~T}$ & 1,57 & $\mathrm{~T}$ & 11,48 & $\mathrm{~T}$ \\
\hline TN1 & 55,33 & $\mathrm{P}$ & 73,04 & $\mathrm{P}$ & 75,07 & $\mathrm{P}$ \\
\hline
\end{tabular}

IS: Intensitas Serangan, T: Tahan, AT: Agak Tahan, P: Peka. 
IRBB5 yang mengandung gen ketahanan $\mathrm{Xa5}$ dan IRBB21 yang mengandung gen ketahanan Xa21.

Varietas diferensial yang memiliki dua gen ketahanan (digenik) dan varietas diferensial yang memiliki lebih dari dua gen ketahanan (multigenik) ternyata memiliki respon yang berbeda dari varietas yang memiliki satu gen ketahanan (monogenik). Hal ini biasa disebut dengan efek pyramiding gene. Efek ini dapat menimbulkan respon positif (tahan), tetapi ada juga yang tidak menunjukkan respon (sama dengan sifat monogenik). Efek pyramiding gene yang positif memberikan respon tahan pada penelitian ini antara lain varietas IRBB50 (Xa4+Xa5), IRBB52 (Xa4+Xa21), IRBB53 (Xa5+Xa13), IRBB54 (Xa5+Xa21), IRBB56 $(X a 4+X a 5+X a 13)$, IRBB57 $(X a 4+X a 5+X a 21)$, IRBB58 $\quad(X a 4+X a 13+X a 21), \quad$ IRBB64 $(X a 5+X a 7+X a 21), \quad$ dan $\quad$ IRBB66 $(X a 4+X a 5+X a 7+X a 13+X a 21)$. Efek pyramiding gene yang tidak memberikan respon terhadap patogen Ras tertentu ditunjukkan pada varietas IRBB51 $(X a 4+X a 13)$, dimana efek tersebut menunjukkan ekspresi yang sama dengan sifat monogenikXa4 dan Xal3 terhadap patogen Ras IV dan Ras VIII.

Uji Fenotipe terhadap Respon Ketahanan pada Galur-Galur Uji. Padi galur uji menunjukkan respon ketahanan yang bervariasi terhadap Ras III, IV, dan VIII (Tabel 3). Pada Gambar 2 dapat dilihat bahwa untuk ketahanan terhadap Ras III, terdapat 7 galur uji yang tahan, 16 galur uji bersifat agak tahan dan 14 galur uji bersifat peka. Respon ketahanan terhadap Ras IV menunjukkan 18 galur bersifat tahan, 13 galur uji bersifat agak tahan dan 6 galur uji bersifat peka. Sedangkan respon ketahanan terhadap Ras VIII menunjukkan 6 galur uji bersifat tahan, 10 galur uji bersifat agak tahan dan 21 galur uji bersifat peka (Gambar 1 \& 2).

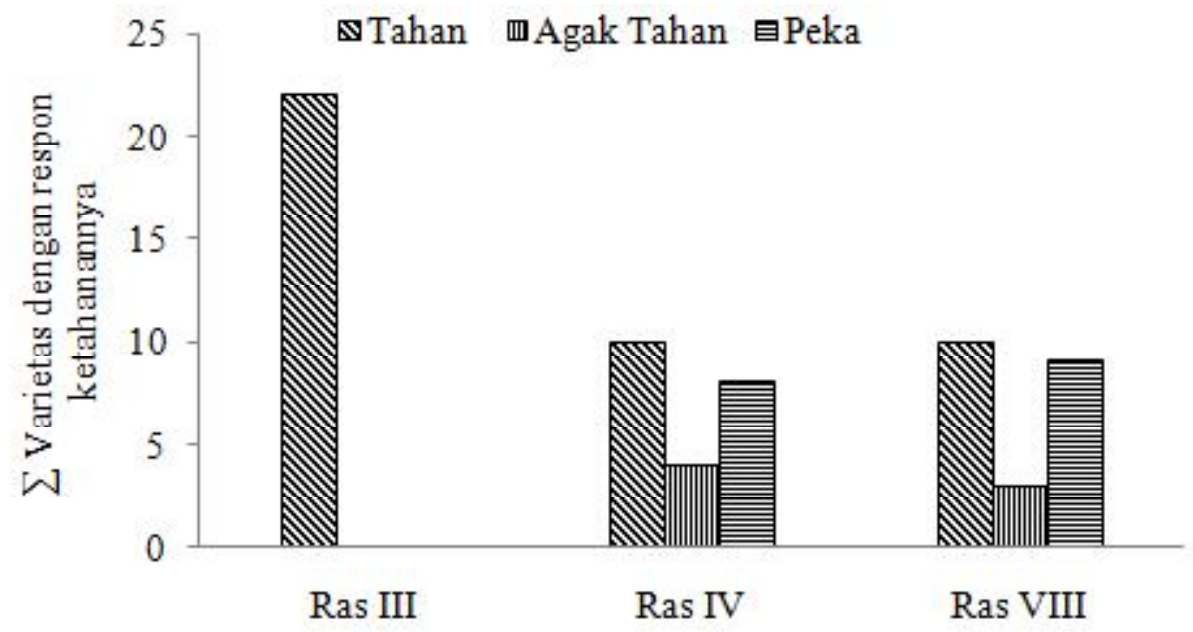

Gambar 1. Ketahanan padi varietas diferensial terhadap Ras III, Ras IV, dan Ras VIII

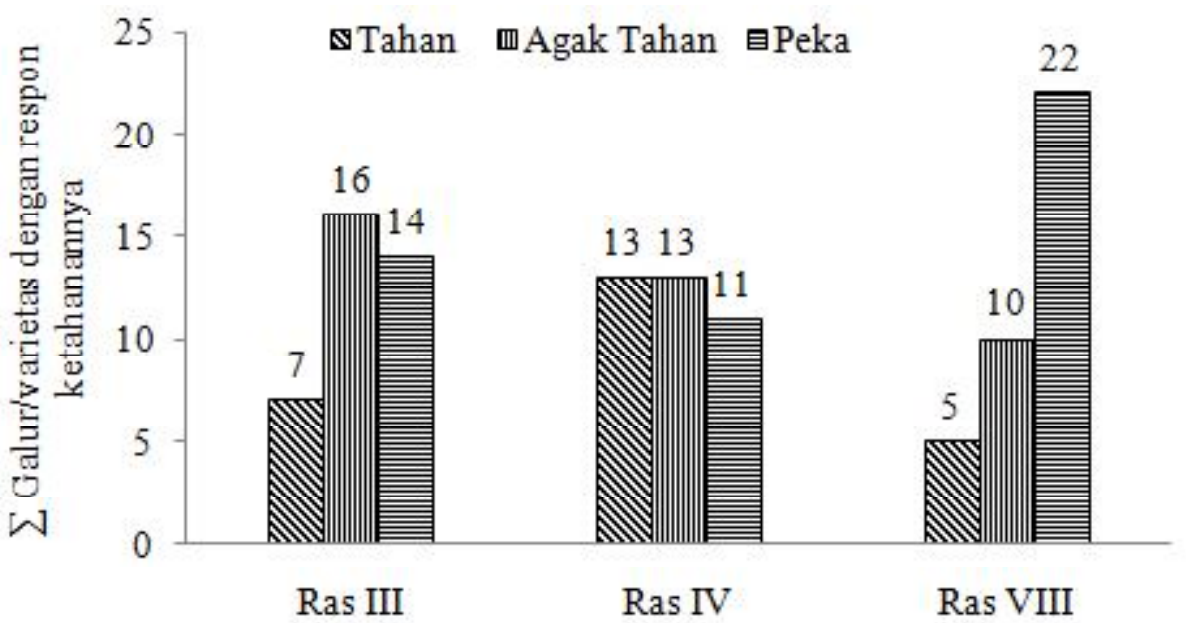

Gambar 2. Ketahanan padi galur uji terhadap Ras III, Ras IV,dan RasVIII 
Dari 37 galur uji, diperoleh 4 galur yang bersifat tahan terhadap semua Ras uji. Pendugaan adanya gen ketahanan pada galur uji tersebut didasarkan pada respon ketahanannya yang sama dengan varietas diferensial yang memiliki gen monogenik (Tabel 4).

Uji Genotipe untuk Survei Polimorfisme. Uji ini bertujuan untuk menyeleksi 208 primer untuk marka terkait gen ketahanan HDB $(\mathrm{Xa})$ tertentu yang bersifat polimorfis pada tanaman kontrol peka TN1 dan tanaman kontrol tahan IRBB7. Jika pada survei polimorfisme ini memperlihatkan pita yang berbeda ukuran pada padi kontrol peka dan padi kontrol tahan, maka marka tersebut bersifat polimorfis. Hal ini mengindikasikan bahwa marka yang digunakan tersebut dapat digunakan dalam seleksi populasi galur uji.

Uji Genotipe pada Populasi Uji. Berdasarkan hasil uji polimorfisme, diperoleh 19 marka bersifat polimorfis dan selanjunya digunakan untuk analisis genotipe populasi uji terkait dengan sifat ketahanan penyakit HDB. Hasil uji genotipe pada populasi uji salah satunya dapat ditunjukkan pada Gambar 3.

Analisis Asosiasi Fenotipe dan Genotipe pada Galur Uji. Berdasarkan analisis fenotipe dan genotipe, diperoleh asosiasi dari keduanya. Asosiasi fenotipe dan genotipe ditunjukkan pada Tabel 5. Hasil analisis asosiasi menunjukkan bahwa Ras III berasosiasi dengan 3 marka spesifik yang mengenali sifat ketahanan pada galur uji yaitu Xa7-STS40, Xa1-STS14 dan Xa4-STS50. Ras IV berasosiasi dengan 3 marka spesifik yang mengenali sifat ketahanan yaitu Xa1-STS5, Xa4-STS50 dan Xa26STS1. Ras VIII juga berasosiasi dengan 3 marka yang menandai sifat ketahanan pada galur uji, yaitu Xa21STS6, Xa7-RM20590 dan Xa7-STS40. Semua Ras berasosiasi marka spesifik dengan nilai $P$-value di bawah 0,05 (Tabel 5).

Tabel 4. Pendugaan gen galur uji

\begin{tabular}{lcccl}
\hline \multicolumn{1}{c}{ Varietas diferensial } & Ras III & Ras IV & Ras VIII & Galur Uji \\
\hline IRBB7 (Xa7) & T & T & T & IR 3822-512-3-2-2 \\
& & & & IR 82571-581-1-2-3 \\
& & & & IR 82571-602-3-2-2 \\
IRBB5 (Xa5) & T & T & AT & BERAS MERAHD1 \\
IRBB21 (Xa21) & T & AT & T & IR 83650-59-2-5-2-2 \\
\hline
\end{tabular}

T: tahan dan AT: agak tahan.

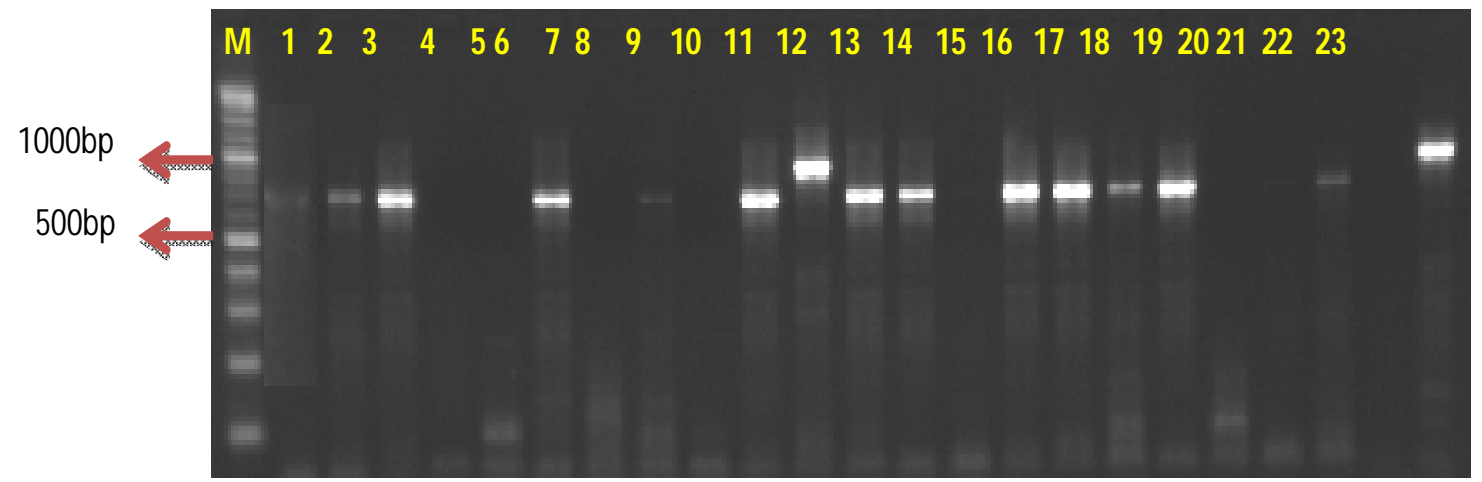

Gambar 3. Salah satu hasil PCR menggunakan primer Xa1-STS5 pada varietas diferensial. Keterangan: M:100bp; 1:IRBB1; 2:IRBB2; 3:IRBB3; 4:IRBB4; 5:IRBB5; 6:IRBB7; 7:IRBB8; 8:IRBB10; 9:IRBB11; 10:IRBB13; 11:IRBB14; 12:IRBB21; 13:IRBB50; 14:IRBB51; 15:IRBB52; 16:IRBB53; 17:IRBB54; 18:IRBB56; 19:IRBB57; 20:IRBB58; 21:IRBB64; 22:IRBB66 dan 23:TN1 
Tabel 5. Hasil analisis asosiasi fenotipe dan genotipe pada galur uji

\begin{tabular}{|c|c|c|c|}
\hline Ras & Marka & P-Value & Galur Uji \\
\hline Ras III & Xa7-OP40 & $0,0001^{\text {** }}$ & $\begin{array}{l}\text { Beras Merah D1 } \\
\text { IR 83822-512-3-2-2 } \\
\text { IR 82571-581-1-2-3 } \\
\text { IR 82571-602-3-2-2 }\end{array}$ \\
\hline Ras III & Xa1-OP 14 & $0,0008^{* *}$ & IR $83822-512-3-2-2$ \\
\hline Ras III & Xa4-OP 50 & $0,0013^{* *}$ & $\begin{array}{l}\text { IR 85627-46-1-2-3 } \\
\text { IR 83822-512-3-2-2 }\end{array}$ \\
\hline Ras IV & Xa1-OP5 & $0,039^{* \pi}$ & $\begin{array}{l}\text { Beras Merah D1 } \\
\text { BMIP-18-4-4-1 } \\
\text { IPBM-32-1-3-3 }\end{array}$ \\
\hline Ras IV & Xa4-OP 50 & $0,036^{*}$ & $\begin{array}{l}\text { IR 82571-581-1-2-3 } \\
\text { IR 82571-602-3-2-2 }\end{array}$ \\
\hline Ras IV & Xa26-OP1 & $0,032^{*}$ & $\begin{array}{l}\text { IR } 83650-59-2-5-2-2 \\
\text { IR } 83689-14-1-2-1-3\end{array}$ \\
\hline $\begin{array}{l}\text { Ras VIII } \\
\text { Ras VIII }\end{array}$ & $\begin{array}{l}\text { Xa21-OP6 } \\
\text { Xa7-RM20590 }\end{array}$ & $\begin{array}{l}0,005^{*} \\
0,013^{*}\end{array}$ & $\begin{array}{l}\text { IR 3822-512-3-2-2 } \\
\text { IR } 82571-581-1-2-3\end{array}$ \\
\hline Ras VIII & Xa7-OP 40 & $0,010^{*}$ & IR $82571-602-3-2-2$ \\
\hline
\end{tabular}

**)P-value $\leq 0,05$ pada $\mathrm{P}$-permutasi; $\left.{ }^{*}\right) P$-value $\leq 0,05$ pada $P$-marker.

\section{SIMPULAN}

Hasil evaluasi ketahanan HDB pada 37 galur uji terdapat 4 galur tahan terhadap ketiga ras HDB yang diujikan yaitu galur : IR 3822-512-3-2-2, IR 82571-5811-2-3, IR 82571-602-3-2-2 dan Beras MerahD1. Hasil dari analisis asosiasi terdeteksi 3 set marka spesifik yang masing-masing set menandai sifat ketahanan terhadap Ras III yaitu Xa7-STS40, Xa1-STS14 dan Xa4-STS50; terhadap Ras IV yaitu Xa1-STS5, Xa4-STS50, Xa26STS1; dan terhadap Ras VIII yaitu Xa21-STS6, Xa7RM20590 dan Xa7-STS40. Marka-marka ini dapat dimanfaatkan untuk membantu proses seleksi galurgalur tahan HDB hasil dari program pemuliaan.

\section{SANWACANA}

Terima kasih disampaikan kepada Balai Besar Penelitian dan Pengembangan Bioteknologi dan Sumberdaya Genetik Pertanian (BB-BIOGEN) yang telah membantu dalam hal pendanaan melalui proyek penelitian Peningkatan Kemampuan Peneliti dan Perekayasa (PKPP) No.X.110, Tahun 2012.

\section{DAFTAR PUSTAKA}

Abdullah B, Brar DS, \& Carpena AL. 2001. lntrogression of bacterial leaf blight resistance gene from Oryza minuta J.B. Presl. Ex C. B. Presl. into new rice type (Oryza sativa L.). Bul Agron. 29(2): 50-58.

[BPS] Badan Pusat Statistik. 2011. Berita Resmi Statistik.No.69/11/Th.XIV. Jakarta. BPS.

Bradbury PJ, Zhang Z, Kroon DE, Casstevens TM, Ramdoss Y, \& Buckler ES. 2007. TASSEL: software for association mapping of complex traits in diverse samples. Bioinformatics. 23(19): 2633-2635.

Doyle JJ \& Doyle JJ. 1990. Isolation of plant DNA from fresh tissue. Focus. 12(1): 13-15.

Fitriyanti. 2008. Keragaman genetik plasma nutfah beberapa genotip padi asal Sumatra Barat berdasarkan analisis penanda RAPD [Tesis]. Padang: Universitas Andalas.

[IRRI] International Rice Research Institute. 1996. Standard Evaluation System for Rice. 4th Ed. IRRI Philippines. 52p. 
Mudingotto PJ, Tusiime G, Asea G, Rubaihayo PR, Gibson P, Tumutegyereize J, \& Lamo J. 2010. Genetics of resistance to bacterial leaf blight in rice germplasm in Uganda. Second RUFORUM Biennial Meeting 20 - 24 September 2010. Kampala (UG): Makerere University.

Siregar AZ. 2007. Hama-hama tanaman padi [Disertasi]. Medan: Universitas Sumatra Utara.

Triny SK, Suryadi Y, Sudir, \& Machmud M. 2011. Penyakit Bakteri Padi dan Cara Pengendaliannya. Bogor: Balai Besar Penelitian Tanaman Padi.

Utami DW, Septiningsih EM, Kadir TS, Nasution A, Hanarida I, \& Suhartini T. 2009. Pencarian alel baru gen-gen untuk ketahanan hawar daun bakteri. Dalam: Buku laporan Balai Besar Penelitian dan Pengembangan Bioteknologi dan Sumber Daya Genetik Pertanian.Bogor. Badan Penelitian dan Pengembangan Pertanian Kementrian Pertanian. Hlm 39-44.
Utami DW, Sutoro, Nurul H, Andari R, \& Ida H. 2011. Keragaman genetik 96 aksesi plasma nutfah padi berdasarkan 30 marka SSR terpaut gen pengatur waktu pembungaan (HD Genes). J. Agro. Biogen.7(2): 76-84.

Wahyudi AT, Meliah S, \& Nawangsih AA. 2011. Xanthomonas oryzae pv. oryzae bakteri penyebab hawar daun pada padi: isolasi, karakterisasi, dan telaah mutagenesis dengan transposon. Makara Sains. 15(1): 89-96. 